Research Article

\title{
Livelihood Dissonance in Sherpa Community
}

\author{
Arjun Karki ${ }^{*}$, Kapil Kafle ${ }^{2}$ \\ ${ }^{1}$ Central Department of Journalism and Mass Communication, Tribhuvan University, Nepal, \\ *Corresponding author email: arjun.urlarj@gmail.com \\ ${ }^{2}$ Editor, Nepal Samacharpatra, National Daily and Training Coordinator in Nepal Press Institute, Email: patrakarita.khoj@gmail.com
}

\author{
Article Information \\ Received: 14 June 2020 \\ Revised version received: 12 July 2020 \\ Accepted: 14 July 2020 \\ Published: 27 July 2020

\section{Cite this article as:} \\ Arjun Karki and Kapil Kafle. (2020) Int. J. Soc. Sc. \\ Manage. 7(3): 159-168. \\ DOI: $10.3126 /$ ijssm.v7i3.29958

\section{*Corresponding author} \\ Arjun Karki, \\ Central Department of Journalism and Mass \\ Communication, Tribhuvan University, Nepal \\ Email: arjun.urlarj@gmail.com \\ Peer reviewed under authority of IJSSM \\ (C) 2020 IJSSM, Permits unrestricted use under the \\ CC-By-NC license.
}

\section{OPEN ACACES}

This is an open access article \& it is licensed under a Creative Commons Attribution Non-Commercial 4.0 International

(https://creativecommons.org/licenses/by-nc/4.0/)

Keywords: Sherpa people; Inhabitants of Himalayas; Climbing Professions; Livelihoods of Sherpa

\begin{abstract}
This study deals with the changing occupations of Sherpa people who has been recognized as 'high altitude porter' for their courage in climbing difficult mountains. After having a lot of in person formal/informal conversation, focus group discussion and in field observations for 15 days with heterogeneous people in Khumbu region of Nepal, the study tried to find reasons of distractions of younger generation in maintaining their ancestral professions. Narrative interview has been conducted with Sherpa mountaineers, business persons, porters, young students and teachers. An effort has been made to analyze the issues of Sherpa community people through cognitive dissonance theory developed by Leon Festinger in 1957. It employs thematic analysis in three categories of participants - professional mountaineers, business people (age: 20 to 35) and high school students (age: 16 to 20) and findings have been discussed under theoretical and policies perspectives. The findings show that Sherpa people are reluctant to continue their ancestral climbing profession because of risks of life, pressure built from their family members, lack of encouragement from the Government and availability of alternatives. The study has reflected many possibilities of future research. The lapses are found in policies, relevant educational curricula, facilities and protection and promotion mechanism of tourism industries, thus, studies in these areas can help shed light on the overall situations of professionalism in this sector.
\end{abstract}

\section{Introduction}

\section{Sherpa Community People}

A news report by Cable News Network (CNN) of 12 July 2017 states that the word 'Sherpa' originally meant 'people from the East' and is pronounced as 'Sharwa' by the Sherpa people themselves. It further states that before Sherpa gained recognition as the mountain climbing people, they were simply the group of people migrated from eastern
Tibet, territory of China to Nepal. These groups of people originally settled in the Solukhumbu district of Nepal at Pangboche village, which has been declared as Sagarmatha National Park in 19 July 1976. These people have migrated via Sikkim, India and Tibet in $15^{\text {th }}$ century and started making a living for many centuries as traders of salt, wool and rice, herders of yaks and cows, and farmers of potatoes, 
barely and buckwheat (The Editors of Encyclopedia Britannica, 12 September 2019). But as Tenzing Norgay Sherpa summited the Mount Everest on 29 May 1953 along with Edmund Hillary (Rand, 1954), news hit across the globe that made Sherpa famous at large. The success did not only motivate the Sherpa community but had established an identity of Sherpa as great climbers in the world. The successful expeditions of Tenzing and Hillary had awarded them a heroic icon that created many followers from around the world. Even within the Sherpa community, it helped to establish climbing as their special profession.

\section{Occupations of Sherpa People}

The Pangboche village is one of the main junctions to scale the Mount Everest, the world highest peak. The Independent (26 May 2013) states that in 1865 the mountain was renamed as Mt. Everest in honor of the Surveyor General of India George Everest, from its original name as Peak 15. However, there was no legal permission to climb the mountains till 1953. Conefry (2014) reveals that Nepal pursued a policy of isolation fiercely protecting their borders and thus there were no tourists, missionaries, and merchants till 1953. But in coordination with the Indian and British embassies a New Zealand team led by Sir Edmund Hillary and Tenzin Norgay Sherpa in 1953 made their glorification (Conefry, 2014). After the successful expeditions of Tenzin Norgay Sherpa, the Sherpa community people gained various glorifying adjectives icefall doctors, porters of high altitudes, snow guides and other such name and fame around the world. In the preceding days, the tourists started searching specifically to Sherpa people for porters, trekkers and climber's guides. And, as Pangboche the Sherpa residence place being situated in the lap of Mt. Everest, Lhotse, Cho Oyu, Makalu and other, they were relatively easily accessible for the mountaineering tourists. Thus, they gradually left their ancestral professions of traders, herders and farmers, and obtained the porters, trekkers and climbing guides as new professions.

\section{Livelihoods of People}

The United Nations Development Program (UNDP) presents 'livelihoods' with various terminologies - making a living, supporting a family, job of the people and other. As a more formal definition, the study includes a definition from Chambers \& Conway as:

\section{A livelihood is sustainable when it can cope with and recover from stress and shocks and maintain or enhance its capabilities and assets both now and in the future, while not undermining the natural resource base (Chambers \& Conway, 1991).}

Livelihood is thus a multi-disciplinary approach without affecting existing natural resources. There are many factors that affect a person's livelihoods. The Department for International Development (DFID) of United Kingdom forwarded a frame of livelihoods, the Sustainable Livelihoods Framework (SLF). The framework consists of four factors as follow:

1. The assets people draw upon

2. The strategies they develop to make a living

3. The context within which a livelihood is developed

4. Those factors that make a livelihood more or less vulnerable to shocks and stresses

(DFID, 1999)

The SLF frame consists of the explanation of these four indicators in which the first one emphasizes on gaining from natural resources, the second deals with the quality of individuals to attract resources, similarly the third indicates about the contextual phenomenon and the final one is the situation which leads individual towards vulnerability.

\section{World Trends in Traditional Livelihoods}

The most important traditional occupations of people were hunting, fishing, collecting firewood, gathering non-timber forest products, agriculture, aquaculture, livestock, traditional medicines, traditional crafts and utensils, household equipment and constructions, traditional arts, drama, music, and many such others. Forest Peoples Program (April 2016) surveyed to find if such occupations are still in practice or decline in different countries. The reports finding confirmed more than 50 percent of the traditional occupations have been declined (p. 4). The study further states that those that remained unchanged or increased have adopted shift in its forms, process and ways of practice. For instance, in agriculture new technologies are in use for farming. In different parts of Asia, indigenous people practice rotational farming, shifting cultivation, and terrace farming and it is not exceptions to Nepal. In Nepal, communities sell their rice in local markets, practice local paper plant cultivation and manufacture, shifting cultivation and planting minor crops in fallow land' (Forest People Program, 2016, p. 4). Report highlights several reasons for shifting occupations of people in different countries including a discouraging governmental policy towards traditional livelihoods. Many communities still report on public policies, laws and regulations that discourage or even outlaw traditional occupations, in a number of cases it is related to misunderstanding of traditional occupations and their effect on biodiversity. An 'enabling and supportive environment' for traditional occupations of indigenous people and local communities, both by government as well as mainstream society, is crucial for these occupations to continue to exist and develop (Forest People Program, 2016). Similarly, report finds other reasons to shift the traditional professions are the type of education of the younger generation of people which do not focus on the traditional business and skills. An enabling and secure environment is not created and it aloof indigenous people from their national resources. Even in many cases, the 
traditional forms of livelihoods have resulted negative effect on its overall results- for instance, low productions, impact on health, environment, excessive uses of energies and other so many (CBS, 2014). Therefore, traditional methods of occupation are neither sustainable nor desirable from an environmental point of views. The Government of Nepal emphasizes for the need to replace or supplement with modern forms of technologies (p. 65). Climbing and working in high altitudes are also traditional occupations of Sherpa people in Nepal that have also been found affected, and as new alternatives emerged and explored gradually, Sherpa people of new generation are leaving their ancestral occupations. This study seeds light on the livelihoods of Sherpa people.

\section{Nepali People's Livelihoods}

The livelihoods of Nepal can be studied under two domainsgeographical and developmental ones. Through the geographical dimension, Nepal is divided into three geographical areas - plains (Tarai), hills and Himalayas. The main occupations of plains is agriculture, in hills there are mix occupations - cattle farming and agriculture whereas in Himalayan regions climbing, cattle farming and business. Nepal has farming field in plains and some parts in hills, but not in Himalayas. The Central Bureau of Statistic shows that there was more than 90 percent of population in agriculture field in 1971 (CBS, 1971). In the successive censuses, there is continuous decrease in this rate. In the population census 2011, it dropped to 64.01 percent (CBS 1971, 1981, 1991, 2001 \& 2011). There may be many reasons behind this simultaneous decline. Chetry (2010) found that the major causes for the occupational changes are the modernization, urbanization and widespread use of the western education system. The advancement of technologies and their utilizations have been causing an occupational shift in another sphere. Therefore, everywhere the changes have been occurring, however, they are rapid in the city and town than in village or the remote part (CBS 1971; 1981; 1991; $2001 \& 2011$ ). With respect to the areas, the survey shows more people made their involvements in the commercial and private sectors.

\section{Caste-Based Occupations in Nepal}

In Nepal from the time of Jayasthithi Malla, caste-based occupations were started. The foundation of Nepali social system lies in the Hindu society. Chetry (2010) claims caste system of Nepali society is based on the Varna system where primary social classification are Brahman, known as priest in occupation, Kshatriyas known as warrior or administrator in occupation, similarly Vaishya (trader), Sudra (labor) and other. From Malla period to the date of today, the age of science and technology, a lot of changes have occurred. Caste isn't seemed playing leading role in order to select the professions in their lives.

\section{Himalayan Livelihoods and Life Style}

The CBS data shows majority number of the Sherpa people has been found habitat of Himalayan region. Mountaineering is their ancestral profession. Their basic source of livelihood is agriculture, livestock farming and transportation of goods and services using the animals- yak, donkey, horse and other. Besides these, hotel business, trekking and porter are their supporting businesses. Presently, they are adopting changes on their livelihoods, professions and ways of cultural celebrations. A substantial number of Sherpa have the attitude of leaving not only the traditional livelihood sources but also the land they were born in. A study of Loland (2006) affirms that the livelihoods of the Sherpa people had shifted from agriculture to tourism. The changing process continuous in most of the community people, however, rapid changes have been noted in the Sherpa community. Rai (2017) claims that Sherpa people who have adopted tourism and trekking business have been converting themselves as international individuals socially and culturally.

The main base of economic life of Sherpa community
has been changed from agro-pastoralism to tourism-
based business. The level of employment and income
of local people has improved. However, tourism has
undermined Sherpa culture by introducing new
values and lifestyles influencing from westerners,
eroded the central role of religion and traditional
value in Sherpa community. For the younger
generation the tourist and their norms of behavior
and patterns of consumption can be seductive. This
is the symptom of losing of cultural value of Sherpa
community and world identity of Sherpa in the
future.

(Rai, 2017)

Despite the credit and names, Sherpa people are found reluctant to work in the high altitude. A substantial number of Sherpa have been found not only leaving the job of climbing and assisting to the climbers as icefall doctors, but they are also migrating to the developed countries, like USA and Europe as permanent residents.

\section{Objective of the Study}

The study tries to understand whether Sherpa people love to continue the livelihoods what their fathers and forefathers followed or want to leave it for the new alternatives. It depicts an account of social and cultural life of the Sherpa people, habitat on the trekking pathway to Mt. Everest base camp from Lukla.

\section{Theoretical Frame}

A theoretical framework can be used to check the study and provides a lens through which researchers can explain and corroborate the findings (Imenda, 2014). This study undertakes Cognitive Dissonance theoretical lens to analyze 
the problems - why Sherpa community people have been leaving their ancestral professions. As usual, there can be many reasons - economics, politics, social and other behind the shift and adoption of new professions. The theoretical framework underpins changing contextual settings of the society through an explorative verification method. This study analyzes Sherpa community people's daily life style how the availability of the modern alternative intervened the traditional ways of life.

Cognitive Dissonance theory has been developed by Leon Festinger in 1957. The theory has a base on social psychology, however closely connected to behavioral psychology by the uses of information. It basically follows testing hypothesis and observation methods with certain experimental standards as the theory was emerged from the socio-psychological experimental verification. Festinger argues dissonance occurs when a person holds two or more beliefs, values or ideas and because of multiple beliefs and ideas, it creates discomfort in an individual which leads people to seek out information to lessen their level of the discomforts and thus the degree of uncertainty will be reduced (Festinger, 1957:162-7). It states that there is a tendency for individuals to seek consistency among the cognitions.

In livelihood of people, economic behavior plays a vital role and according to rational choice theory by Adam Smith the actions of human being is fundamentally 'rational' in character and that people calculate the likely costs and benefits of any action before deciding what to do (Scott, 2000). But the 'rationality' in character can only be attained after passing through the phases of cognitive dissonance. A study by Gilad, Kaish and Loeb (1986) affirms that because of cognitive dissonance, the decision makers make full uses of information to maximize his utility. The two theories classical theory of rational choice and cognitive dissonance provide a frame to look at how people make decisions and management to bring changes in their behavioral phenomenon (Akerlof and Dickens, 1982). Generally, better choice in life can be made when individuals know about all pros and cons of their alternatives. On this regard, cognition plays an undeniable role as it is associated with 'information processing' and 'behavior' of an individual (Houwer, Barnes-Holmes \& Barnes-Holmes, 2016).

The study focuses on the causes regarding the changing livelihoods of Sherpa community people. Sherpa people are not following their ancestral professions of mountaineering and working in high hills which was once their main profession (Conefry, 2014). Easy access of information due to modernization creates awareness in people and brings change in behavior leading to standardization of their livelihoods. Therefore, cognitive dissonance theory provides a lens to look into the changing Sherpa's psycho- social phenomenon leading to reluctance of maintaining the ancestral processions.

\section{Methodology of the Study}

The study employs narrative analysis as a leading methodology. Narrative analysis is a method to record experiences through construction and reconstruction of personal stories (Webster \& Mertova, 2007, p. 1). This method records such stories and provides lessons of life ahead in human activities. In this study, the researchers have immersed in Sherpa community for 15 days and talks with various professional people. Both formal and informal conversation have been made and recorded. Two methodological tools are used for data collectionformal/information conversations and observations. The researchers themselves delved into the field of studies to have better understanding and gain feeling of the realities. The on-site (in-situ) observations have embarked lights on gaining a deeper understanding of Sherpa community and their livelihoods.

Researchers have observed and interacted with Sherpa community people within their environment. The participants were not homogeneous; they were diverse with respect to their professions and age. The participants comprise of- hotel businessman, students, trekkers, and community people. This study encompasses 10 individuals' formal interviews and observations. The study has also employed Focus Group Discussion. It categorized the participants under three broad groups - the first category is the professionals or employers in the mountaineering field likes trekkers, porters or the guides. Consulted ones were mostly climbers, trekkers and mountaineers. The second category is the businessmen - wholesalers or retailers including hoteliers, and the last category is the secondary school students with age ranging from 16 to 20. The FGD has been conducted with secondary school students from the core area of Sherpa community.

The participants of the study are from different locations and sectors in Sherpa community- one or two person(s) from each sector taken randomly. The sites of the study are Lukla, Phakding, Namche bazar, Dingboche, Pangboche, Lobuche and Gorakshep (2,860 m to 5,164 m of heights). 14 key informants' interviews have been conducted on these places. These are the villages of Sherpa people that lie on the way from Lukla to the Everest Base Camp (EBC). Besides these, Hillary Secondary School at Khumbu is also the site location.

Under narrative, thematic analysis has been made. The study presents direct quote of the participants and it tried to interpret their meaning depending in their physical and social context. For the proper and systematic study, the researchers have made interaction with the participants in three groups. The first group includes interaction with professionals, the second group is the interaction with 
young people and the last group is a FGD with school children at Hilary Secondary School at Khumjung in Solukhumbu district. Finally, the finding has been consolidated and mapped with theoretical frame and policies of the government of Nepal in a separate topic.

\section{Interaction with Mountaineering Professions}

Climate change and influence of the western culture and lifestyle are also other strong reasons of shifting the profession. Nima Dolma Sherpa (36) [1] and Furdiki Sherpa (42) [2], widows of the Mountain climbers- husbands swept away by the avalanche while climbing Mount Everest in 2013 and 2014 respectively, expressed their dissatisfaction about the future of the Himalayas related professions. They indicate that climbing will remain only in the story because of melting snow from the Himalayas due to increasing pollution, rise in temperature and frequent climate change. They strongly urge on the needs of robust mechanismspolicies, awareness, and course books and skills-oriented trainings to conserve and sustain the professionalism. 'New generation have no any interest on ancestral professions (trekking, climbing and porter) adopted by our forefathers,' Nima Doma Sherpa emphasized in the formal talks. Both of them expressed that their husbands climbed for money to look after the family and children rather than to gain name and fame. For them, they had no any alternative of the livelihoods in order to feed their families.

As the alternative of the livelihood appeared, Sherpa people gave up the risky business. Some of them have many opportunities and alternatives of the livelihood for todaybusiness, foreign jobs, and other. So, most of the participants have expressed the common view. They no more like to risk their lives in climbing and trekking. Tshering Tenzing Sherpa (38) [3], the in-charge of Sagarmatha Pollution Control Committee (SPCC) for the EBC and the proprietor of Pumori Guest House and Restaurant in Namche Bazar (3,440 m height), stressed, 'security is the main reason that deviated my thinking of getting on the mountains. Why should I take the risk of life if my guiding responsibilities have been fulfilled without climbing the top?' Angngima Sherpa (55) [4], an influential businessman and social workers at Lobuche $(5000 \mathrm{~m}$ height) expressed, 'Only a foolish person climbs the snowy and sloppy mountains for the money. People have multiple choice of earning now.' Angngima has got experiences of rescuing many people from mountains- foreigners as well as locals. He urges that Sherpa have to find appropriate alternative for their livelihoods and quit climbing professions. 'The climbing accounts cost of precious life and tears of bloods in our beloved eyes,' Angngima expresses.

Because of high risks and lack of securities (rewards and recognitions), most of the Sherpa people don't want to climb mountains. However, people who are poor and have no any alternatives to sustain their families, they often intends to climb up. Dalamu Sherpa (88) [5], a hotel owner's mother in Phakding, a place between Namche and Lukla, asserts that if any family member plans to climb the mountain, she cannot sleep and eat well. She is worried of life of climber, and prays to the God for safety and healthy returns. She reiterates, 'climbing mountain, taking the risk of life for the sake of feeding stomachs is a pathetic situation. I don't like to send or let them go for the high altitude works to face avalanche and the crevasse or glacier calving under the feet that swap away our beloved ones.'

\section{Findings and Discussion}

\section{Interaction with Business Persons}

Despite the challenges in mountaineering professions, many young people want to temporarily take risk of life for the betterment of their future. Rajendra Neupane (32) [6], who runs hotel at Lukla Bazar (2800 m height), reflects that he was a tourist trekking guide in high altitude for more than a decade but he never felt comfort in the profession. Therefore, he saved his earning and started a secure business. He mentions, 'Being a tourist guide I used to earn more money but I was never happy. But now my profession is safe and I am happy with my wife and children.' While working Rajendra knew a lot of Sherpa people who wanted to quit climbing professions for new alternatives. He revealed a similar mentality of his Sherpa colleagues.

Nuri Sherpa (31) [7], a Graduate in Pharmacy and runs a medical shop in Kathmandu, also works as a Tourist Guide for the foreigner up to the EBC. He made a couple of trips with foreigners in half month duration. The researcher confronted twice with Nuri Sherpa on the way to the EBC. He plans to make five trips in second season of 2019 to the EBC and returns at home for his marriage ceremony. 'I'm going to Dharan, there is my bride, for the marriage' he seemed happy to share the program and disclosed the tentative plan of the life, 'though I've not any plan to climb the mountain, going only up to the EBC, but I don't think, guide will be my long-lasting livelihood, it is just for few years of the young age.' He is thinking of pharmacy would be his long-lasting livelihood for the family.

Similar to Nuri, most of the young boys are found temporarily working to earn money and get settlement in their lives. But while inquiring to the young girls, they showed disinterest in boy who hold climbing as their profession. Pemba Jagmu Sherpa (18) [8], a student of grade 10 at Hillary Secondary School in Khumjung Valley $(3,800$ $\mathrm{m}$ height), shared that she is happy to have a Sherpa boyfriend who is engaged in multi-professions - trekking, travelling, tours and hotel business professions. She doesn't like to have a groom who is depended on climbing and working at risky mountains. She recalled, 'I have seen the wives and children of crying and facing livelihood problems after demise of their husbands in mountains.' 
Because of these reasons, the negativity of the climbing profession is prevailed in Sherpa community people. Young girl's parents are not interested to lend their daughters to a climbing professional family. Jangmu Sherpa (17) [9], a grade 9 student and works as Kitchen Assistant at Sonam Hotel in Phakding (place in between Namche and Lukla), stated that she doesn't see any future with a boy who is of climbing profession. She explained, "climbers are just like a soldier fighting at the border. They don't have any certainty of life. I love the boy who has a secure job. It doesn't matter that the job is a source of name and fame for the person.' She prefers to have an honest loving boy and the secured livelihood.

\section{FGD with High School Students}

FGD has been conducted at Hillary Secondary School in Khumjung Valley. Khumjung is one of the renowned villages of the Sherpa community where most of the habitats either have got the experiences of successful climbing of Mt. Everest and other popular mountains or attempting for the climbing.

Shambhu Prasad Bastola (55) [10], the Principal of Hillary Secondary School at Khumjung for 33 years, has produced thousands of School Leaving Certificate/School Education Exam (SLC/SEE) graduates. According to him, hardy 5 percent of the students have been engaged in the climbing mountain business whereas about 20 percent associated with the trekking profession regardless of their caste identities. 'Most of the climbers belonged to Sherpa community but in trekking there are Rai, Gurung, Tamang, Limbu, Brahman, Chhetri and several other equally' shared his observations. According to him, as the livelihood options have been emerged, attractions towards the climbing mountains have been declining along with the passage of time.

One close group interaction was held in order to understand ideas and visions of the youth about climbing profession. 27 Participants included students of grade 8, 9 and 10 at Hilary Secondary School in Khumjung Valley (3,790 m height) in Solukhumbu, held on $3^{\text {rd }}$ November 2019.17 boys and 10 girls were participated and sat on the group discussion. Among the participants, 10 boys and four girls were from the community of Sherpa. Out of 27 with the age category of 16 to 20 , only 2 students showed interest to follow the practices of climbing the snowy mountains that were carried by their parents and earlier generations. These two students expressed their interest to climb the mountain as their earlier generations gave the logic that the profession gives the identity of bravery for the name and fame.

During the survey, 10 girl participants were responded anonymous way that none of them will be selecting their boy-friend or husbands from the field of mountain climbers. Five of them paid interest with medical doctor, three of them went with journalists and remaining two went with pilot and singer for one each.

Finding of the survey is shown in the Table 1.

Despite the family pressure, Sherpa people maintained the risky jobs because of the poverty and with a hope of better life afterwards. They are passing through a state of 'dissonance' for either to hold this risky job in Himalayans or search a better alternative. Therefore, all the participants had passed/have been passing through a state of mental dissonance - some of them who had already made good utilization of information technologies to avoid state of discomforts had a better life. Modernization has facilitated in access to information to all classes of Sherpa people and because of which some other people who are still involved in this profession are looking ahead for better alternative. Unfavorable government policies and availability of livelihood alternatives are the main reasons on declining interest of climbing the mountains as a profession in Sherpa people. At the time of Tenzing Norgay, Sherpa people had no choice except climbing professions for their livelihoods. Despite the risks of life, Tenzing and his contemporary Sherpa had adopted climbing professions to meet their daily needs more than the name and fame in the world. But now Sherpa have a lot of choices, they are medical doctor, pilot, engineer, CEOs in the big enterprises and several others (Nepal Samacharpatra, 2019).

Table 1: Data collected from survey

\begin{tabular}{|l|l|l|l|}
\hline S. No. & Groom with the profession & Selecting number & Percentage \\
\hline 1 & Doctor & 5 & $50 \%$ \\
\hline 2 & Journalist & 3 & $30 \%$ \\
\hline 3 & Pilot & 1 & $10 \%$ \\
\hline 4 & Singer & 1 & $10 \%$ \\
\hline
\end{tabular}


Angngima Sherpa [4], who is an influential business person in the areas, says 'life security is basic needs of people and now Sherpa community people have started to understand this facts.' Sherpa further says that the Government of Nepal doesn't have any policy to encourage and sustain Sherpa community in their profession. Another participant, Ms. Furdigi Sherpa's [2] husband died while climbing leaving three small kids orphaned. She had no options to take care of her kids and thus she was compelled to follow her husband's pathway. Leaving three daughters at home, she prepared to risk her life towards the deadly snowcapped mountain. Luckily, Ms. Furdigi had successfully climbed Everest about 6 month before the date of interview. She expresses her dissatisfaction with the Government policy. She says, 'the Government didn't even waive royalty of NRs. 80,000 which could have met my basic expenses in the climbing journey.'

According to her, new generation people of Sherpa community are not interested in mountain climbing profession. They have several other secured professions now for their livelihoods. 'Life was hard for the grandfathers and fathers with the limited livelihood options that even made them a porter on the tough mountains, but now educated young generations have several options to adopt in their lives for the secured future', Furdigi expresses her opinions. She further states:

\section{Sherpa and other people who scale the Mt. Everest and other snowy peaks are just like army who sacrifice their lives for the sake of country. Army sacrifices their lives in boarder and we do so on the way to mountains. But army personnel's families are provided social security after their death and we get nothing.}

According to her, life threats are one-part, other aspects are social security and financial supports, as both of these are in negative scales. So, new generation people are found critical towards the profession of their parents in Khumbu region. To fill up the gap, gradually, people of other castes like Rai, Tamang and other are replacing the roles of 'high altitude worker' that was once led by the Sherpa ancestors. These new tribes are also keeping records as high-altitude workers though foreign climbers still prioritize to hire Sherpa as their guides.

But Tsering Tenzin Sherpa [3], the in-charge of SPCC, reminded an incident to the researchers that blamed whole Sherpa community people. He stated:

It was an issue in 2016 that none Sherpa community people brought the tourist to the peak of Mt. Everest, and unfortunately avalanche killed all of them and blamed went to the Sherpa community and skills as none Sherpa community claimed themselves as
Sherpa and brought the tourists because foreigners prioritize us.

\section{(T.T. Sherpa, Personal Communication, 4 October 2019)}

Rai, Limbu, Tamang and some other community people look similar to Sherpa physically and are equally brave and courageous to climb the mountains. But the legacy was created by Mr. Tenzing Norgay Sherpa who facilitated Mr. Edmund Hillary as a first person to climb the Mt. Everest on 29 May 1953. Therefore, most of the climbers chose supporting staffs to Sherpa people as far as possible.

\section{Conclusion}

Sherpa is not just a caste of the residents in Himalayas and mountainous region in Nepal but it is an identity that has become the part of nationality of the country, Nepal. Sherpa ancestors had adopted climbing professions because they had no alternatives for their livelihoods. Despite the high risks and pains, the ancestors used to earn and could buy the momentary happiness with the hard-earned money for their family members. Even today, out of ten old aged people in the Sherpa community, the researchers found at least one had successfully climbed the highest peak. But such spirits have not been noticed in the young people. The youngsters have no charm to serve as 'icefall doctors' in their future. These youngsters are well equipped with modern technologies and are skillful in accessing information required to make a better decision for their life. Thus, young Sherpas are exploring for better career alternative so that they can secure their lives. Even among the interested youngsters, their elder family members are trying to divert them because of lack of securities and risks of lives. Moreover, they are aware of the impact of biodiversity and threats of fast melting snows and moving rocks. The study finding shows a dire necessity of provisions to sustain Sherpa workers in order to enhance tourism industry. The Government must encourage interested workers by improving the policies in their favorable. Similarly, success stories of none Sherpa people must be projected before the foreign tourists planned manner so that national identities been expressed equally shared among other Nepali people who are skillful and still interested to climb the mountains so far. As Sherpa is pride of the country today for the climbing stories, Rai, Tamang, Limbu, Thapa and other people would also be the similar identity for the country. But, it would not be possible without the governmental policy and plan with the appropriate priority.

\section{Notes:}

[1] Nima Dolma Sherpa (36) \& [2] Furdiki Sherpa (42), interviewed together on $28^{\text {th }}$ October 2019 , their husbands were high altitude worker, demised in 2013 and 2014 respectively by avalanche. Furdikiis a mother of three girl children for running family and getting education for her 
kids, she has a small teashop serving Momo food items at Dingboche $(4,400 \mathrm{~m})$. She could not manage her life even at husband's house because of lacks of opportunities of livelihoods. Finally, she decided to climb the Mt. Everest for getting out of the grievances and the problems around. Nima Doma, habitat of Khumjung valley has also the same fate as Furdiki. Her husband demised in an accident of glacier calving in 2014 leaving her along with two kids. Both of them have decided to climb the Mt. Everest to show the society that they are not that much hopeless and helpless though lost their husbands in the patriarchal society. They got success to step on the top of the Everest in 2019. Now, all their kids have been sponsored by the generous organizations and individuals for their studies. One elder daughter of Furdiki lives in the US and remaining are admitted in the schools in Kathmandu with the hostel facilities. They expressed their tough decision of climbing the mountain leaving their loving kids. 'It was our last option to jump out from the trap of vicious circle of poverty' both of them have the same words to respond to the researcher. Both of them cried several times during the interviews, and praying for the God in order to get out of the situation of traps for all the people who are facing risks of their precious lives to address the livelihood problems.

[3] Tshering Tenzing Sherpa (38), interviewed on $4^{\text {th }}$ November 2019, a proprietor of Pumori Guest House and Restaurant in Namche Bazar $(3,440 \mathrm{~m})$, is also an in-charge of Sagarmatha Pollution Control Committee (SPCC) for the Everest Base Camp (EBC). According to him, he is very much concerned with the security issues of the climbers. He has never tried to get on the top of the Everest though bagged the experiences of climbing some of the camps above the base point of it. But, he has spent several days and nights at base camp, where we can observe massive glaciers - rocks and stones are on the top of the snows, and one feels melting and flowing of liquid under the ground during nights when living under the tents. He is taking care of his old age father and mother along with beautiful wife and son in Namche Bazar. He is associated with the trekking and traveling business without any threats of life. 'Not only I am happy in my family, my 80 year old father is happy with my decision of not taking the risk on the mountains, same is my wife and other members in the family. Since I'm in the family; I must take care of my beloved ones. I can be considered responsible member if I take care of the interests of other members.' According to him, wives and family members of the climbers could not sleep and eat in the days of climbing that goes weeks and months sometimes.

[4] Angngima Sherpa (55), interviewed on 30 October 2019, one of the influential businessmen and social-workers made his comment and observation at his hotel and restaurant at Lobuche $(5,000 \mathrm{~m})$ during the interview. According to him, he has never been entered into the school for study, he hardly reads and writes Nepali language, but he has invested in a couple of hotels, the Heli transportations and several others. He is found frequently talking with the family members at messenger, WhatsApp and several others means of the internet facilities. His assistants were bringing the hot water in a bowl for washing his hands so that he could eat his food at his place. He was found maintaining his luxurious life even at the high altitude. In our conversation he said: "I urge all the Sherpa fellow to find the appropriate alternative for the livelihood and quit the concept of climbing mountain at the cost of precious life and tears of the bloods on the eyes of beloved ones' shared the concept and encouraged them with the words as 'even a person like me who is far from the opportunities of reading and writing became an influential business person in the Khumbu region, all the new members will have better options for the profession and career in the society."

[5] Dalamu Sherpa (88), interviewed on $27^{\text {th }}$ October 2019, at Sonam hotel is located in Phakdin $(2,670)$ way to Namche from Lukla. Dalamu is mother (not biological) of hotel owner. She is found working on her own way- praying and worshiping the God, roaming to the garden, taking care of flowers and chatting with the family members. Dalamu communicates in Sherpa language, the only medium to communicate with other. She can't speak Nepali and any other language. With the support of her family members, researcher came to know that if any family member goes to climb the mountain, she can't sleep and eat well; all the way she is worried for the life of the climber. But, she can't do anything in order to save the life of climber except praying to the God. She responded, 'climbing mountain, taking the risk of life for the sake of feeding stomachs is a pathetic situation, I don't like to send or let them go for the high altitude works to face avalanche and the crevasse or glacier calving under the feet that swap away our beloved ones. I keep praying the God even today though I don't have any family members to climb the mountains.'

[6] Rajendra Neupane (32) interviewed on $25^{\text {th }}$ October 2019, runs a hotel in Lukla Bazar $(2,800 \mathrm{~m})$ for last one year, who used to be a tourist trekking guide in high altitude for more than a decade. He didn't feel the comfort in trekking and guiding, and shifted his profession to hotel business. As he got married and became a father of two kids, he changed his mind to find a secured, comfortable and regular type of business. Finally, he established a hotel in Lukla and quit his guide profession. Nowadays, he doesn't have that much earning as he used to, while he was a tourist Guide, but he is happy with the little earning that he makes out of his hotel business. He says that now his profession is safe and makes happy to his wife and child who stay in Dhading, his birth district. The researchers made his daily life observation for two evenings, being as guest of his hotel named Khumbu Lodge and Resturant, he is found cool and 
calm and enjoying with his coworkers, and interacting with his guests with smiles in his face. He seemed happy.

[7] Nuri Sherpa (31), interviewed on $29^{\text {th }}$ October 2019, is working as a Tourist Guide of the foreigner upto the Everest Base Camp. He was encountered twice in the research period, first at Dingboche and second in Lukla. In trekking season, he seemed really busy to guide the foreigners as he made two trips to the base camp in a research period of two weeks. He is a Graduate in Pharmacy and run a medical shop in Kathmandu but love to earn handsome remuneration and tips in two seasons in a year. He made five trips in second season of 2019 to the Everest Base Camp and returned at home for his marriage ceremony. 'I'm going to Dharan, there is my bride, for the marriage' he seemed happy to share the program and disclosed the tentative plan of the life, 'though I've not any plan to climb the mountain, going only up to the Everest base camp, but I don't think, guide will be my long-lasting livelihood, it is just for few years of the young age.' He is thinking of pharmacy would be his long-lasting livelihood for the family.

[8] Pemba Jagmu Sherpa (18), interviewed on $28^{\text {th }}$ October 2019, a tall and beautiful girl, student of Hillary Secondary School at Khumjung Valley $(3,800 \mathrm{~m})$, also known as green valley, was fellow trekker of the researchers for four hours from Namche to Pangboche. During the journey, she shared her feeling and rough plan of her life. She will be happy to have a Sherpa boy who is engaged with trekking, traveling, tours, hotel business and similar type of service oriented business, but not interested to have a groom who is depended on climbing and working at the risky mountains. 'I'm just student of $10^{\text {th }}$ grade now, not hurry to get married before the age of 20, planning to go Kathmandu for the higher education after completing the SEE in the village' described her with full of honesty on her eyes. She has seen the wives and children crying, and facing the livelihood problems after demising their husbands in the mountains climbing around.

[9] Jangmu Sherpa (17), interviewed on $27^{\text {th }}$ October 2019, a student of $9^{\text {th }}$ grade, working as a Kitchen Assistant at Sonam Hotel, Phakding. She was found contributing her time for serving the guests and domestic chores. As she gets little release from her kitchen and dealing with the guest, she is found engaged in internet games in mobile phone sets. Some of the male youth customers were found interested to chat and talk with her. She also seemed enjoying with the young guests. As asked whether she likes to get boyfriend from the business of climbing mountains and working at high altitude, she responded rightly that she does not see any future of life, 'climbers are just like a soldier fighting at the border who do have any certainty of life. I love the boy who has a secure job. It doesn't matter that the job is a source of name and fame for the person.' She prefers to have a honest loving boy and the secured livelihood.

[10] Shambhu Prasad Bastola (55), interviewed on $3^{\text {rd }}$ November 2019, is the Principle at Hillary Secondary School, Khumjung for last 33 years. He has produced thousands of SLC/SEE graduates. According to him, hardy 5 percent of the students have been engaged in the climbing mountain business whereas about 20 percent associated with the trekking profession regardless of their caste identities. 'Most of the climbers belonged to Sherpa community but for the trekking you can see Rai, Gurung, Tamang, Limbu, Bahun, Chhetri and several other equally' shared his observations. According to him, as the livelihood options have been emerged, attractions towards the climbing mountains have been declining along with the passage of time.

\section{Conflict of Interest}

Authors declare no conflict of interest with this study.

\section{References}

Akerlof GA \& Dickens WT (1982) The Economic Consequences of Cognitive Dissonance. American Economic Review 72: $307-319$

CBS (1971, 1981, 1991, 2001, 2011) National Population and Housing Census. Kathmandu Planning Commission, the Government of Nepal. Retrieved from https://cbs.gov.np/population/

CBS (2014) Population Monographs of Nepal: Volume III (Economic Demography). Kathmandu: Central Bureau of Statistics.

Chambers R \& Conway G (1991) Sustainable Rural Livelihoods: Practical Concepts for the 21st Century. Retrieved February 3, 2010. Retrieved from http://www.smallstock.info/reference/IDS/dp296.pdf.

Chetry DB (2010) Changing Occupational Pattern Among the Bishowkarmas: A Case Study of Hemja VDC. Himalayan Journal of Sociology \& Antropology 1: IV.

CNN (2017, July 17) The Sherpa Cheat Sheet: 9 things you were embarrassed to ask. Retrieved from: https://edition.cnn.com/travel/article/sherpafacts/index.html.

Conefry M (2014) Everest 1953: The Epic Story of the First Ascent. UK: Oneworld Publications.

DFID (1999) Sustainable Livelihoods Guidance Sheets, Numbers 1-8, London: Department for International Development (also available on www.livelihoods.org).

Festinger L (1957) A Theory of Cognitive Dissonance. California: Standard University Press.

Forest Peoples Programme (2016) Status and Trends in Traditional Occupations: Outcomes of a Rapid Assessment. England: Forest Peoples Programme. Retrieved from https://www.forestpeoples.org/sites/fpp/files/publicatio 
n/2016/05/fpp-status-trends-trad-occupations-englishweb-16.pdf.

Gilad B, Kaish S \& Loeb DP (1986) Cognitive Dissonance and Utility Maxmization: A General Framework. Journal of Economic Behavior and Organization 8: 61-73.

Houwer JD, Barnes-Holmes D \& Barnes-Holmes Y (2016) What is Cognition? A Functional- Cognitive Perspectives. Retrieved from: https://www.researchgate.net/publication/308749950 What is Cognition A FunctionalCognitive Perspective

Nepal Samacharpatra (2019, November 7) Difficult to get wives for mountain climbers. Kathmandu: Nepal Samacharpatra.

Loland L (2006) Commons of Identity: Sherpa Identity Management. Dhaulagiri Journal of Sociology and Anthropology 1: 176-192. Retrieved from https://doi.org/10.3126/dsaj.v1i0.288.

Rai DB (2017) Tourism Development and Economic and SocialCultural Consequences in Everest Region. The Geographical Journal of Nepal 10: 89-104, p. 89. Retrieved from : https://pdfs.semanticscholar.org/ec5d/cedb60537eca05f 366dd829677e1b79e92f9.pdf.
Rand C (1954, June 5) The Story of First Sherpa to Climb to the Top of Mt. Everest. The New Yorker.

Scott J (2000) Rational Choice Theory. In: Browning G, Halcli A \& Webster, F (2000) Understanding Contemporary Society: Theories to the Present. (P. 126-138). New Delhi: Sage Publication.

The Editors of Encyclopedia Britannica (12 September, 2019) Sherpa. Retrieved from: https://www.britannica.com/topic/Sherpa-people.

The Independent (2013, May 26) Conquering Everest: 60 Facts about the World's Tallest Mountain. Retrieved from: https://www.independent.co.uk/environment/nature/co nquering-everest-60-facts-about-the-worlds-tallestmountain-8632372.html.

UNDP (n.d.) Guidance Note of Recovery Livelihood. Retrieved from UN Office for Disaster Risk Reduction (UNDRR): https://www.unisdr.org/files/16771 16771guidancen oteonrecoveryliveliho.pdf.

Webster L \& Mertova P (2007) Using Narrative Inquiry as a Research Method: An Introduction to Using Critical Event Narrative Analysis in Research on Learning and Teaching. New York: Rutledge. 